\title{
EVALUATION OF LOW-DRIFT NOZZLES IN AGROCHEMICAL APPLICATIONS IN ORCHARDS
}

\author{
Sergio Behmer ${ }^{*}$, Alcides Di Prinzio ${ }^{1}$, Guillermina Striebeck ${ }^{1}$, and Jorge Magdalena²
}

\begin{abstract}
Fruit production demands several phytosanitary treatments per year. The efficiency of these treatments is affected by product loss because of drift, a situation that is aggravated by frequent high winds and the presence of a substantial rural population. The objective of this study was to evaluate the distribution and to quantify product losses in fruit orchard applications. Fluorescent tracers with air-blast sprayers were applied, using air-induction hollow cone nozzles, compared to conventional hollow cone nozzles. To evaluate drift, pipes cleaner were placed on columns behind the adjacent row to the treated one, and for the losses under the tree, Petri dishes were located below the treated row; for the distribution in the tree, leaves were collected from the canopy. The deposits were quantified with a fluorimeter, and the surface of the leaves with an area optical meter. Both nozzles produced equal quantity of deposits in the canopy with a minor quantity in the top part. The low drift sprinklers obtained $75 \%$ less drift than the standard nozzles; however, the losses under the tree were 50\% higher. To conclude, the utilization of low drift nozzles in fruit orchards is an alternative to mitigate pollution of the environment.
\end{abstract}

Key words: orchards, sprayers, drift, air-induction nozzles.

\section{INTRODUCTION}

When agrochemicals are applied to trees or bushes, only part of the active ingredient used is retained, depending on the vegetative state, the technique employed and environmental conditions at the time of application (Baraldi et al., 1993; Doruchowski, 1993; Solanelles et al., 1996).

The unretained product is lost as sedimentation in the soil and as drift, representing a major source of environmental contamination. Several authors have contributed to a more precise understanding of these concepts, defining the spray carried outside the area by wind as exodrift; while deposits in the soil from the expulsion and runoff of large drops originating from high application volumes are defined as endodrift.

The Environmental Protection Agency of the USA (EPA) estimates that from 10 to $60 \%$ of applied agrochemicals drift more than $300 \mathrm{~m}$ from the treated

\footnotetext{
${ }^{1}$ Universidad Nacional del Comahue, Facultad de Ciencias Agrarias, Cinco Saltos, Río Negro, Argentina.

*Corresponding author (sbehmer@uncoma.edu.ar).

${ }^{2}$ Instituto Nacional de Tecnología Agropecuaria (INTA), Estación Experimental Alto Valle, Gral. Roca, Río Negro, Argentina.

Received: 28 March 2009.

Accepted: 10 August 2009.
}

area (Salyani and Cromwell, 1992). This question is even more relevant in regions with intensive cultivations that are characterized by a high density of rural populations, with housing, schools, health centers, etc. in proximity of agricultural centers. Vercruysse et al. (1999) found product deposits up to $40 \mathrm{~m}$ from the application site, which while they 20 times as low as those found at $5 \mathrm{~m}$, represent between 2.5 and $4.5 \%$ of the volume sprayed. Copes et al. (2006) found deposits from an application in a fruit orchard up to $48 \mathrm{~m}$ from the treated area, which emphasizes that the rural population located within this distance from agricultural sites is at risk of contamination.

Huijsmans et al. (1993) indicated that the air-assisted sprayers used in fruit orchards, while they facilitates the transport and penetration of the drops to the interior of the canopy of the trees, can also increase drift and deposits of the product in the soil, and argued that it is necessary to improve the application technique in order to reduce environmental contamination.

Heijne et al. (2004) presented a series of methods to reduce drift indicating their degree of mitigation. They included the use of windbreak barriers, spraying tunnels, foliage sensors, reflective screens, as well as different management practices such as leaving areas free from cultivation or only spraying trees on the edges of orchards on the side away from the field. In the same sense, Di 
Prinzio et al. (2004) evaluated a spraying tunnel design and found a reduction of drift on the order of $95 \%$ compared to air-blast sprayers with divergent flow. However, Cross et al. (2003) affirmed that while sprayers with tangential flow fans and spray tunnels with a confined application present a substantial reduction in drift, they are not widely used owing to their high cost and/or reduced operational flexibility.

Holownicki et al. (2004) affirmed that the wind influences the spray cloud, affecting uniformity and increasing product loss, which can be mitigated by the use of larger drops produced by air-induction nozzles. They evaluated distribution and loss with air-induction flat fan nozzles with air in comparison to conical projection nozzles and found that total deposits in the tree were significantly higher with the low-drift nozzles, but with less uniformity than with the control nozzle.

Wenneker et al. (2004) evaluated drift using airinduction flat fan nozzles compared to conical projection nozzles, with two air flows from the fan, and found that with more flow the reduction of drift was on the order of $55 \%$ at $5 \mathrm{~m}$ from the sprayer and $23 \%$ at $7 \mathrm{~m}$; while with lower air flow the reduction was from 75 and $43 \%$ respectively.

Zhu et al. (2005) evaluated product loss with air-blast sprayers equipped with flat-fan air-induction nozzles compared to cone projection nozzles. Columns were located in plots without cultivation at distances of 15, 30, 60 and $91 \mathrm{~m}$ from the point of application. Samplers were located in the same plot at heights of $0.9 ; 2.8$ and $3 \mathrm{~m}$. It was found that the low-drift nozzles presented lower deposits than the conventional nozzles at a distance of 15 $\mathrm{m}$ and a height of $3 \mathrm{~m}$. In relation to loss to the soil, the results were the reverse, deposits being higher with the low-drift treatments.

Onorato and Tesouro (2004) evaluated the behavior of air-induction nozzles in comparison to conventional nozzles, both with cone projection, in a wind tunnel with an air velocity of $13 \mathrm{~km} \mathrm{~h}^{-1}$ and collected the sprayed liquid in horizontal distribution bank and quantified it gravimetrically. Their results indicate that the airinduction nozzles significantly reduced drift.

With regard to the efficiency of the treatments, Frießleben (2004) did not find significant differences in the control of different pests in either ground crops or vineyards and apple orchards, using air assisted nozzles in comparison to the same applications with conventional hollow cone nozzles. Nevertheless, he affirmed that further studies would be necessary to define more precisely its effects in applications with insecticides where the targets are small or the underside of leaves.

The objective of the present work was to evaluate distribution in the tree and quantify product loss in applications in fruit orchards, using cone projection airinduction nozzles.

\section{MATERIALS AND METHODS}

The study was carried out at an apple orchard (Malus domestica Borkh.) trained on trellises, with $4 \mathrm{~m}$ between rows and plants with a height of $3.5 \mathrm{~m}$ and a thickness of $1.6 \mathrm{~m}$. The required application rate was $1300 \mathrm{~L} \mathrm{ha}^{-1}$, and was calculated according to the TRV method (Cichón and Magdalena, 1992).

\section{Treatments}

Low-drift treatment: cone projection air-induction nozzle. Arc equipped with five upper nozzles of $2.01 \mathrm{~L} \mathrm{~min}^{-1}$ each, and two lower nozzles of $1.52 \mathrm{~L} \mathrm{~min}^{-1}$ each, on each side. Total flow: $26.18 \mathrm{~L} \mathrm{~min}^{-1}$; pressure $2000 \mathrm{kPa}$.

Conventional treatment: cone projection nozzle. Arc equipped with five upper nozzles of $2 \mathrm{~L} \mathrm{~min}^{-1}$ each, and two lower nozzles of $1.5 \mathrm{~L} \mathrm{~min}^{-1}$ each, on each side. Total flow: $26.0 \mathrm{~L} \mathrm{~min}^{-1}$; pressure $2000 \mathrm{kPa}$.

\section{Equipment used}

The same air-blast sprayer was used in both treatments, at a working velocity of $0.83 \mathrm{~m} \mathrm{~s}^{-1}$. The application rates obtained were 1309 for the low-drift treatment and $1300 \mathrm{~L}$ $\mathrm{ha}^{-1}$ for the conventional treatment. The airflow from the fan was $25000 \mathrm{~m}^{3} \mathrm{~h}^{-1}$, slightly higher than what was required by the orchard, with an average velocity of $9.6 \mathrm{~m} \mathrm{~s}^{-1}$ at $2 \mathrm{~m}$ from the nozzle mouth (Figure 1).

\section{Climatic conditions}

Winds calm, temperature: $18{ }^{\circ} \mathrm{C}$, relative humidity: $70 \%$.

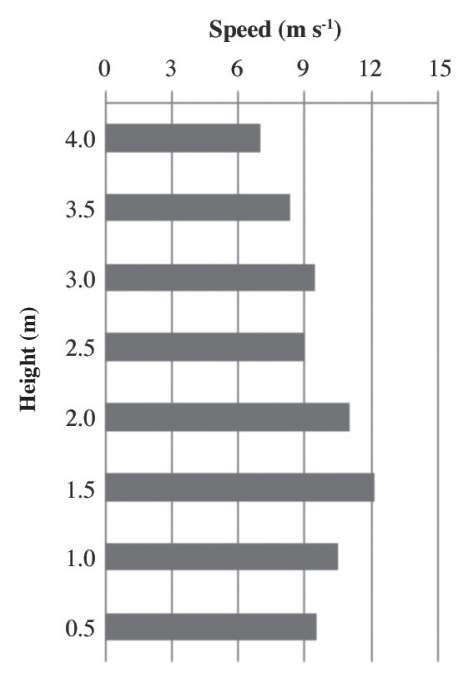

Figure 1. Profile of fan velocities at $\mathbf{2} \mathrm{m}$ from its axis. 


\section{Sampling methodology and evaluation}

Sodium fluorescein $\left(\mathrm{C}_{20} \mathrm{H}_{10} \mathrm{Na}_{2} \mathrm{O}_{5}\right)$ (Sigma-Chemical F6377, Steinheim, Germany) was applied at a dosage of $80 \mathrm{~g} \mathrm{ha}^{-1}$ as a tracer, with the treatment on both sides of the assayed row.

Two pairs of pipe cleaners were used to collect drift, located at heights of 2 and $6 \mathrm{~m}$ over four columns $2 \mathrm{~m}$ apart and located behind the row adjacent to the treated row, defining a sampling line of $7 \mathrm{~m}$ parallel to the application.

Loss under the trees was collected in four Petri dishes located at $0.5 \mathrm{~m}$ distance under the treated row.

Twenty leaves were collected at heights of 1,2 and 3 $m$ to evaluate the distribution in the tree.

The concentrations of deposits found in the washing water of the collectors (pipe cleaners Petri dishes and leaves) were determined with a fluorometer (Kontron SFM 25, Milan, Italia). The leaf surfaces were determined with an optical foliar area meter (Li-Cor, LI 3100, St. Louis, Nebraska, USA).

\section{Experimental design}

An entirely randomized experimental design was performed and four replications were conducted, gathering all the samples before beginning the following replication. Statistical software was used for the ANOVA, and Tukey test was used, with a $0.05 \%$ level of significance, to compare means.

\section{RESULTS}

\section{Distribution on the tree}

The results indicate that the two nozzles obtain an equal quantity of deposits on the tree canopy, both providing a lower quantity in the upper part than in the lower (Table 1 and Figure 2).

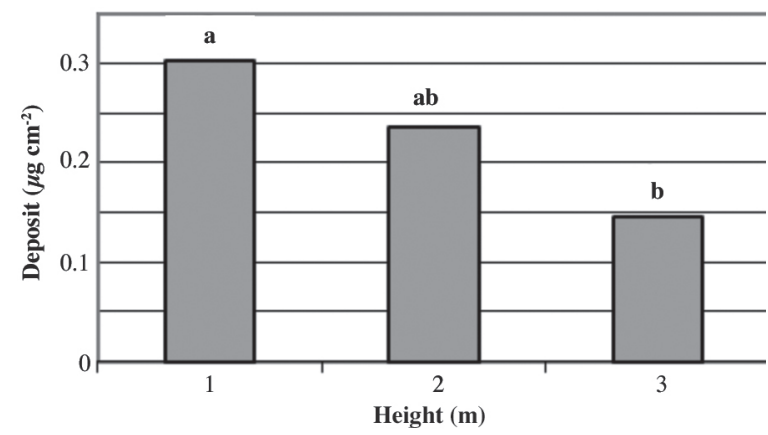

Different letters indicate significant differences according to the Tukey test $(\alpha=0.05)$.

Figure 2. Average distribution of the two treatments in the canopy.
Table 1. Total deposits on the canopy.

\begin{tabular}{lc}
\hline Treatments & Deposits \\
\hline & $\mu \mathrm{g} \mathrm{cm}^{-2}$ \\
Low-drift & $0.201 \mathrm{~A}$ \\
Conventional & $0.256 \mathrm{~A}$ \\
\hline
\end{tabular}

Different letters indicate significant differences according to the Tukey test $(\alpha=0.05)$.

The ANOVA did not allow for affirming that the deposits found in upper parts of trees were independent of the treatments. This indicates that the two nozzles had the same degree of difficulty in distributing deposits. Nevertheless, the low-drift nozzles showed greater uniformity at the heights considered (Figure 3).

\section{Drift}

Total deposits at $7 \mathrm{~m}$ distance from the application site with the low-drift treatment were $60 \%$ less than the drift resulting from conventional nozzles. Considering only the deposits found at a height of $6 \mathrm{~m}$, a $75 \%$ reduction was observed in airborne spray over the canopy (Figure 4).

There were no differences between the two treatments in deposits at a height of $2 \mathrm{~m}$ (Figure 4).

\section{Deposits in the soil}

The deposits in the Petri dishes under the trees with the low-drift nozzles treatment were $50 \%$ greater than those produced by the conventional nozzles (Table 2 ).

\section{DISCUSSION}

The air-induction nozzles reduced drift, which concurs with what was found by Onorato and Tesouro (2004) in the wind tunnel, although working under field conditions and with an air current velocity produced by the fan that was three times as high as that used by the aforementioned authors. On the other hand, the reduction of drift at a distance of seven meters from the application site was on

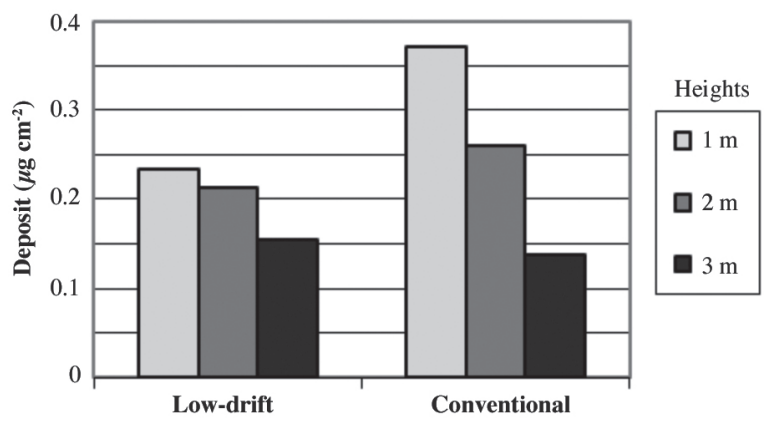

Figure 3. Distribution of each treatment at different heights. 


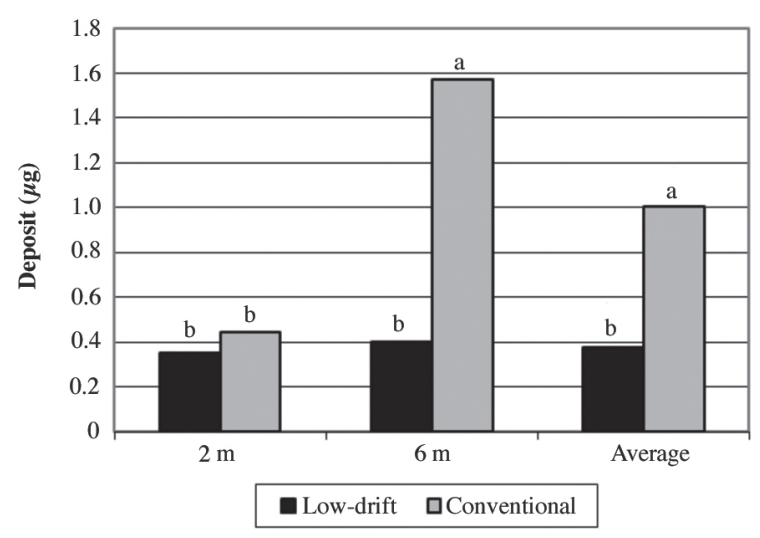

Different letters indicate significant differences according to the Tukey test $(\alpha=0.05)$.

Figure 4. Deposits beyond targets (pipe cleaners in columns).

Table 2. Deposits beyond the target (Petri dishes in the soil).

\begin{tabular}{lc}
\hline Treatments & Deposits \\
\hline & $\mu \mathrm{g}$ \\
Low-drift & $18.99 \mathrm{~A}$ \\
Conventional & $21.11 \mathrm{~B}$
\end{tabular}

Different letters indicate significant differences according to the Tukey test $(\alpha=0.05)$

the same order of magnitude as what was described by Wenneker et al. (2004) for flat fan nozzles.

This reduction is evidenced mainly at a height of $6 \mathrm{~m}$, where the spray is more exposed to the influence of the wind, which concurs with what was affirmed by Hollownicki et al. (2004). This behavior is similar to what was described by Zhu et al. (2005), who observed that the drift from the application with the low-drift treatment is not only proportionally less, but also is found at a lower height than drift caused by conventional conical projection nozzles. These considerations explain the greater losses found under the row. However, to concur with the findings of the aforementioned authors, it would be necessary to extend the sampling in the soil along a line perpendicular to the treated row and in the same direction as the wind.

In terms of distribution on the tree, it was observed that total deposits were similar for the two nozzles, which is consistent with Hollownicki et al. (2004). However, the cone projection low-drift nozzles used in this study showed a better distribution on the trees than the conventional nozzles. This result differs from what was found by the aforementioned authors, possible because of the differences in projection between flat fan and conical nozzles, possibly owing to the principle of projection of the fan nozzle compared to the conical projection.
Based on the results obtained, the low-drift nozzles present a similar behavior to that of conventional nozzles in terms of distribution in the canopy, but with a better aptitude for preventing loss of the application in the immediate area of the treatment.

Nevertheless, it is appropriate to conduct further studies to evaluate the efficacy of the phyto-therapeutic treatments in fruit orchards, with more exhaustive evaluation of endo-drift and quantification of exodrift, with the object of more precisely establishing its environmental impact, coinciding with the appreciations of Hollownicki et al. (2004) and Frießleben (2004).

\section{CONCLUSIONS}

The use of cone projection nozzles with air-induction in fruit orchards confines product loss to the immediate area of the application. Consequently, they constitute a valid alternative to mitigate environmental contamination.

\section{RESUMEN}

Evaluación de boquillas antideriva en aplicaciones de agroquímicos en huertos frutales. La producción frutícola exige varios tratamientos fitosanitarios anuales, cuya eficiencia se ve afectada por la deriva. Esta situación se agrava por la alta frecuencia de vientos y por la existencia de una importante población rural. El objetivo del trabajo fue evaluar la distribución en el árbol y cuantificar las pérdidas de producto en aplicaciones en huertos frutales. Se aplicó un trazador fluorimétrico utilizando un pulverizador hidroneumático en dos versiones: A) con boquillas de cono con inducción de aire, y B) con boquillas de cono estándar. Para evaluar la deriva se colocaron limpiadores de pipas en columnas ubicadas detrás de la fila adyacente a la tratada. Las pérdidas debajo del árbol se recolectaron en placas Petri ubicadas debajo de la fila tratada. Para evaluar la distribución se recolectaron hojas de la copa del árbol. La concentración de los depósitos se determinó mediante una técnica fluorimétrica y la superficie de las hojas mediante un medidor de área foliar óptico. Los resultados indican que ambas boquillas producen igual cantidad de depósitos en la copa del árbol, con menor cantidad en su parte superior. Las boquillas de inducción de aire presentaron una deriva $75 \%$ inferior a la deriva de las boquillas estándar; mientras que debajo del árbol sus pérdidas fueron $50 \%$ mayores. Se concluye que la utilización de boquillas antideriva en huertos frutales es una alternativa para mitigar la contaminación del ambiente.

Palabras clave: fruticultura, pulverizaciones, deriva, boquillas con inducción de aire. 


\section{LITERATURE CITED}

Baraldi, G., S. Bovolenta, F. Pezzi, and V. Rondelli. 1993. Air, assisted tunnel sprayers for orchard and vineyard: First results. p. 265 -272. In Symposium International sur les Techniques D'application des Produits Phytosanitaires [International Symposium on Pesticides Application Techniques], Strasbourg, France. 22-24 September 1993. Vol. 1. Association Nationale de Protection des Plantes, Paris, (France); British Crop Protection Council (Royaume Uni), Paris, France.

Cichón, L., y J.C. Magdalena. 1992. Avances en la determinación en los volúmenes apropiados a pulverizar en los distintos montes de manzanos en el Alto Valle de Río Negro y Neuquén. Rivista di Agricoltura Subtropicale e Tropicale 86(2):357-362.

Copes, W., A. Di Prinzio, S. Behmer, y G. Striebeck. 2006. Contaminación del aire por deriva de pulverizaciones. 118 p. In XXIX Congreso Argentino de Horticultura, Catamarca. 20-23 de Septiembre 2006. Asociación Argentina de Horticultura (ASAHO), La Consulta, Mendoza, Argentina.

Cross, J.V., P.J. Walklate, R.A. Murray, and G.M. Richardson. 2003. Spray deposits and losses in different sized apple trees from an axial fan orchard sprayer. 3. Effects of air volumetric flow rate. Crop Protection 22:381-394.

Di Prinzio, A., S. Behmer, J. Magdalena, y G. Striebeck. 2004. Evaluación comparativa de dos técnicas de aplicación de agroquímicos en manzanos de alta densidad. Agro-Ciencia 20(2):73-83.

Doruchowski, G. 1993. Use of tunnel sprayers in orchards and berry plantations. p. 281-288. Symposium International sur les Techniques D'application des Produits Phytosanitaires [International Symposium on Pesticides Application Techniques], Strasbourg, France. 22-24 September. Vol. 1. Association Nationale de Protection des Plantes, Paris (France); British Crop Protection Council (Royaume Uni), Paris, France.

Frießleben, R. 2004. Balancing drift management with biological performance and efficacy. p. 72-79. International Conference on Pesticide Application for Drift Management, Waikoloa, Hawaii. Washington State University, Pullman, Washington, USA.

Heijne, B., M. Wenneker, and J. Van de Zande. 2004. Accepted spray drift reduction methods in fruit growing in the Netherlands. p. 53. Proceedings of International Conference: Environmentally Friendly Spray Application Techniques, Warsaw, Poland. 4-6 October. Research Institute of Pomology and Floricultura, EU Research Centre of Excellence in Sustainable Pomology, Skierniewice, Poland.
Holownicki, R., G. Doruchowscki, W. Swiechowski, and A. Godyn. 2004. Influence of nozzle type and wind velocity on spray distribution within the tree canopy. p. 85-86. Proceedings of International Conference: Environmentally Friendly Spray Application Techniques, Warsaw, Poland. 4-6 October. Research Institute of Pomology and Floricultura, EU Research Centre of Excellence in Sustainable Pomology, Skierniewice, Poland.

Huijsmans, J.F.M., H.A.J. Porskamp, and B. Heijne. 1994. Orchard tunnel sprayers with reduced emission to the environment. Results of deposition and emission of new types of orchard sprayers. p. 297-304. Symposium International sur les Techniques D'application des Produits Phytosanitaires [International Symposium on Ppesticides Application Techniques], Strasbourg, France. 22-24 September. Vol. 1. Association Nationale de Protection des Plantes, Paris (France); British Crop Protection Council (Royaume Uni), Paris, France.

Onorato, A.A., y M.O. Tesouro. 2004. Desempeño antideriva de una boquilla de pulverización agrícola de cono hueco inducida por aire. RIA 33(3):3-13.

Salyani, M., and R.P. Cromwell. 1992. Spray drift from ground and aerial applications. Transaction of the American Society of Agricultural Engineers 35:11131120.

Solanelles, F., A. Fillat, C. Pifarré, and S. Planas. 1996. A method of drift measurement for spray applications in tree crops. International Conference on Agricultural Engineering. Paper 96 A-133. AgEng96, Madrid, España.

Vercruysse, F., S. Steurbaut, S. Drieghe, and W. Dejonckheere. 1999. Off target ground deposits from spraying a semi-dwarf orchard. Crop Protection 18:565-570.

Wenneker, M., B. Heijne, and J. van de Zande. 2004. Effect of air induction nozzle (coarse droplet), air assistance and one-sided spraying of the outer tree row on spray drift in orchard spraying. p. 55-56. Proceedings of International Conference: Environmentally Friendly Spray Application Techniques, Warsaw, Poland. 4-6 October. Research Institute of Pomology and Floricultura, EU Research Centre of Excellence in Sustainable Pomology, Skierniewice, Poland.

Zhu, H., H. Guler, R.C. Derksen, and H.E. Ozkan. 2005. Comparison of airborne and ground spray deposits with hollow cone nozzle, low drift nozzle and drift retardant. p. 73-78. Proceedings of $9^{\text {th }}$ International Congress on Mechanization and Energy in Agriculture, Izmir, Turkey. 27-29 September. Ege University, Faculty of Agriculture, Izmir, Turkey. 